\title{
Role of TEP in the microbial food web structure. II. Influence on the ciliate community structure
}

\author{
Xavier Mari ${ }^{1,3, *}$, Fereidoun Rassoulzadegan ${ }^{1}$, Corina P. D. Brussaard ${ }^{2}$ \\ ${ }^{1}$ Marine Microbial Ecology Group, Observatoire Océanologique, Laboratoire d'Océanographie de Villefranche, \\ UMR 7093, BP 28, 06234 Villefranche-sur-Mer Cedex, France
}

${ }^{2}$ Royal Netherlands Institute for Sea Research, Department of Biological Oceanography, PO Box 59, 1790 AB Den Burg, Texel, The Netherlands

${ }^{3}$ Present address: Institut de Recherche pour le Développment (IRD), Centre de Nouméa, BP A5, NC-98848 Noumea, New Caledonia

\begin{abstract}
The structure of the bacterial population (free vs. attached bacteria), variations in bacterial abundance and ciliate group composition were monitored as a function of transparent exopolymeric particle (TEP) concentration during Phaeocystis globosa blooms that developed in mesocosms. Two ciliate groups dominated at different stages of the blooms. The oligotrichous ciliate Strombidium spp. were dominant during the growth phase of the blooms, when TEP volume concentration was lower than $20 \mathrm{ppm}$. The hypotrichous ciliate Euplotes spp. emerged and became dominant after blooms peaked, when TEP concentration reached values between 20 and 50 ppm. The succession from Strombidium spp. to Euplotes spp. was closely related to TEP variation. Strombidium spp. depletion was apparently not caused by a reduction of prey availability due to TEP aggregation, as the bacterial concentration increased over time and the fraction of available bacteria for Strombidium spp. remained close to $90 \%$, irrespective of variations in TEP concentration. Instead, the results of incubations conducted by adding $S$. sulcatum to seawater collected in the mesocoms suggest that Strombidium spp. disappearance may have been caused by direct TEP-mediated aggregation of the ciliates. The emergence of Euplotes spp. coincided with the formation of macroaggregates (favored by high TEP concentration), which provide them with the physical support required for feeding on attached bacteria. Our results suggest that variations of the size in the TEP pool may induce a ciliate population succession, modify the size distribution of the bacterial population and ultimately control the microbial food web structure and function.
\end{abstract}

KEY WORDS: Transparent exopolymeric particles $\cdot$ Phaeocystis globosa $\cdot$ Ciliates $\cdot$ Strombidium Euplotes $\cdot$ Succession $\cdot$ Microbial food web $\cdot$ Bacteria

\section{INTRODUCTION}

Since the discovery of transparent exopolymeric particles (TEP) a decade ago (Alldredge et al. 1993), many studies have focused on the effect of environmental changes on the TEP pool characteristics and distribution. The aims of these previous studies on TEP were to define their source, describe their mode of formation and discuss their fate in relation to ecosystem function. One of the main outcomes was to show that the size of the TEP pool is highly variable and depends on various factors, such as phytoplankton bloom events and seasonal vari- ations (Passow \& Alldredge 1994, Riebesell et al. 1995, Mari \& Kiørboe 1996, Grossart \& Simon 1997, Hong et al. 1997, Mari \& Burd 1998, Mari et al. 2001, Passow et al. 2001), growth stage and phytoplankton species (Schuster \& Herndl 1995, Grossart \& Simon 1997, Hong et al. 1997, Grossart et al. 1998, Mari \& Burd 1998, Mari 1999, Passow 2002), turbulent regime (Stoderegger \& Herndl 1999, Passow 2000), light regime (Hong et al. 1997) and carbon dioxide concentration (Engel 2002).

Field studies conducted in various regions of the ocean indicate that TEP volume concentration can vary by more than 2 orders of magnitude, depending on the 
trophic status of the area (Passow \& Alldredge 1994, Passow et al. 1994, Kiørboe et al. 1998, Mari \& Burd 1998) and on phytoplankton bloom dynamics (Mari \& Kiørboe 1996, Mari \& Burd 1998, Mari et al. 2001). Due to their physico-chemical properties TEP play a key role in coagulation processes (Kiørboe \& Hansen 1993, Dam \& Drapeau 1995, Mopper et al. 1995, Passow \& Alldredge 1995, Hansen \& Kiørboe 1997). Consequently, variations in the size of the TEP pool affect the overall particle size spectra by increasing aggregation rates and efficiency (Alldredge \& Jackson 1995, Jackson 1995, Jackson \& Burd 1998).

As most protozooplankton select their food according to size (Bernard \& Rassoulzadegan 1990, Epstein \& Shiaris 1992, Sherr et al. 1992, Simek \& Chrzanowski 1992, Simek et al. 1994, 1995, 1997, Pernthaler et al. 1996), selective removal of picoplankton-size particles (e.g. bacteria for bacterivorous protozoans) should depend both on the intrinsic particle size and on its stage of aggregation (i.e. inclusion into aggregates and size of the aggregates). As particle size spectra are modified via TEP-mediated coagulation processes, food abundance for a given ciliate group may be affected by changes in TEP volume concentration. Mari \& Rassoulzadegan (2004, this volume) showed that the availability of picoplankton-size particles for the ciliate Strombidium sulcatum was reduced when TEP volume concentration increased. Whether changes in TEP concentration in the field modify the structure of the microbial food web is still unknown. Enhanced TEP concentration may disadvantage heterotrophic bacterivorous ciliates, such as Strombidium spp., by aggregating their food source (Mari \& Rassoulzadegan 2004) and the subsequent formation of large aggregates may favor the emergence of ciliate groups adapted to macroaggregate-rich environments, such as Hypotrichida ciliates (Caron et al. 1982, Davoll \& Silver 1986, Artolozaga et al. 2000, Woerner et al. 2000).

The aim of this work was: (1) to study changes in the ciliate community structure as a function of TEP concentration during Phaeocystis globosa blooms, (2) to examine the repartition of the bacterial population over the size spectra in order to assess the availability of bacteria for micro-grazers, and (3) to discuss the role of TEP produced during P. globosa blooms in the community structure of microbial food webs.

\section{MATERIALS AND METHODS}

Mesocosms. Three 8501 indoor mesocosms were filled with natural coastal North Sea water enriched with nitrate and phosphate in order to reach the following initial N:P ratios: 16 (40:2.5 $\mu \mathrm{M}$, Mesocosm 1), 4 $(40: 10 \mu \mathrm{M}$, Mesocosm 2) and 44 (66:1.5 $\mu \mathrm{M}$, Mesocosm
3). No silicate was added. Total concentrations of the limiting nutrient were determined in order to reach similar a Phaeocystis globosa biomass in all 3 mesocosms. P. globosa were grown at $15^{\circ} \mathrm{C}$, with a $12 \mathrm{~h}$ light:12 $\mathrm{h}$ dark cycle and under a light intensity of $150 \mu \mathrm{E} \mathrm{m}^{-2} \mathrm{~s}^{-1}$. Each mesocosm was inoculated with $1 \% \mathrm{v} / \mathrm{v}$ of an exponentially growing P. globosa culture at the beginning of the experiment. The water in mesocosms was kept in motion to prevent sedimentation and wall growth (C. P. D. Brussaard et al. unpubl. data). Chlorophyll a data were provided by C. P. D. Brussaard et al. (unpubl. data). This study was part of a large joint effort aimed at investigating the effect of nitrogen to phosphorus ratios on P. globosa bloom dynamics during a mesocosm study. Since our objectives within this framework were to describe the effect of TEP pool accumulation on the ciliate community structure, the eutrophication issue was not examined. In our study, we consider the mescosms as experimental triplicates of the role of TEP as a factor controlling the ciliate community structure.

Samples for determination of TEP, bacteria and ciliates were collected from inside each mesocosm during 5 sampling occasions covering the main phases of Phaeocystis globosa blooms, i.e. initial phase, early exponential phase, late exponential phase, senescent phase and post senescent phase (i.e. when chlorophyll a concentration reached pre-bloom levels). All samples were immediately filtered for TEP and bacteria slides preparation (see following sections).

Incubations. Incubations, aimed at determining the role of TEP as a loss factor for the ciliate Strombidium sulcatum, were conducted in triplicate with seawater collected from each mesocosm during the 5 sampling occasions described above (a total of 45 incubations were conducted). Prior to incubation with S. sulcatum, seawater was pre-filtered through a $200 \mu \mathrm{m}$ mesh in order to remove large aggregates and mesozooplankton. The ciliate $S$. sulcatum was added to $250 \mathrm{ml}$ subsamples to yield a final concentration of ca. 10 ciliates $\mathrm{ml}^{-1}$ (initial concentration $\sim 1000 \mathrm{ml}^{-1}$ ). Prior to inoculation, $S$. sulcatum were maintained in stationary-phase on a wheat-grain media at $15^{\circ} \mathrm{C}$. Incubations were conducted at $15^{\circ} \mathrm{C}$ under continuous light intensity $\left(150 \mu \mathrm{mol}\right.$ photon $\left.\mathrm{m}^{-1} \mathrm{~s}^{-1}\right)$ and the bottles were gently shaken twice a day. Time-course samples were taken at $24 \mathrm{~h}$ intervals for $2 \mathrm{~d}$. S. sulcatum was counted in $100 \mathrm{ml}$ sub-samples fixed with alkaline Lugol's solution (final conc. $2 \%$ ) and refrigerated until analysis. Blanks were prepared as above without addition of ciliates, but with ciliate growth media, filtered by gravity onto $0.4 \mu \mathrm{m}$ polycarbonate filters.

TEP determination. TEP slides were prepared following Passow \& Alldredge (1994). Aliquots (2, 5 and $10 \mathrm{ml}$ ) of each sample were filtered through $0.2 \mu \mathrm{m}$ 
polycarbonate filters (Osmonics, Poretics), in order to avoid potential artifacts linked to coagulation in the filter funnel (Mari \& Kiørboe 1996). TEP retained on the filter were stained with $500 \mu \mathrm{l}$ of a solution of Alcian Blue, and transferred to a microscope slide using the Filter-Transfer-Freeze technique (Hewes \& HolmHansen 1983). For each slide, 10 images were taken under the microscope at 100 $\times, 200 \times$ and $400 \times$ magnifications using a digital camera. For each image, all TEP were counted and sized using a semi-automatic imageanalysis system. The cross-sectional area of each TEP was measured, and its equivalent spherical diameter (ESD) was calculated. For each sample, counts from the 3 magnifications were combined and TEP were classified according to their ESD into 20 logarithmic size classes (Mari \& Burd 1998). TEP size distributions were described using a power relationship (Mari \& Rassoulzadegan 2004).

Bacterial concentration. The abundance of nonattached bacteria (so called 'free') in each mesocosm was determined in $5 \mathrm{ml}$ samples filtered onto $0.2 \mu \mathrm{m}$ pore polycarbonate black filters after fixation with glutaraldehyde (final conc. $1 \%$ ) and staining with DAPI for $10 \mathrm{~min}$ (final conc. $0.5 \mathrm{\mu g} \mathrm{ml}^{-1}$ ) (Porter \& Feig 1980, King \& Parker 1988). Free bacteria were counted in 10 fields on each slide with an epifluorescence microscope at $1000 \times$ magnification. Total bacterial abundances were determined using flow cytometry (FacsCalibur, Becton Dickinson) according to Marie et al. (1999) (C. P. D. Brussaard et al. unpubl. data).

TEP-attached bacteria and bacteria fraction available for ciliate grazing. The number of TEP-attached bacteria was estimated for each sample by combining the TEP size spectra with a relationship between TEP size and number of attached bacteria. Since this relationship was not established during the present study, we used a relationship obtained from re-examination of data from Mari \& Kiørboe (1996). During their study of a spring bloom, the number of TEP-attached bacteria $(n)$ scaled with TEP size (diameter, $d_{i} \mu \mathrm{m}$ ) raised to an exponent of $1.48\left(n=0.45 d^{1.48} ; r^{2}=0.82 ; \mathrm{n}=340\right)$ during the growth phase of the bloom and of $1.05(n=$ $1.38 d^{1.05} ; \mathrm{r}^{2}=0.67 ; \mathrm{n}=140$ ) during the senescent phase, i.e. after the bloom peaked. Since no other study has provided tools that allow prediction of the fraction of TEP-attached bacteria from TEP size spectra, the above relationships were used.

Ciliate concentration and community composition. For ciliate counts and group determination in each mesocosm and during the incubations with Strombidium sulcatum, $100 \mathrm{ml}$ samples were fixed with alkaline Lugol's solution (final conc. $2 \%$ ) and refrigerated until analysis. Aliquots were settled for $>12 \mathrm{~h}$ in a $10 \mathrm{ml}$ Hydrobios chamber. The total surface area of the chamber was examined at $200 \times$ magnification using an inverted microscope. For protistan concentration and community composition in the mesocoms, all the ciliates were enumerated and the different groups identified according to their morphological characteristics. During the incubations with $S$. sulcatum, the fraction of ciliates attached to mucous aggregates was estimated only for the added ciliate species, in order to distinguish between ciliates that may become attached to aggregates during preparation and handling of the fixed samples (considered as artifacts) and the ciliates that naturally become attached to mucous aggregates (due to TEP stickiness).

\section{RESULTS}

\section{TEP concentration and TEP size spectra}

TEP occurred in significant concentrations (i.e. $>5 \mathrm{ppm}$ ) on all sampling occasions and in all mesocosms (Fig. 1). TEP volume concentration increased continuously from Day 0 to Day 20, from 5.4 to $118.5 \mathrm{ppm}$, 6.1 to $76.1 \mathrm{ppm}$ and 5.9 to $115.9 \mathrm{ppm}$ in Mesocosms 1, 2 and 3, respectively. TEP volume concentrations were low until Day 9 in all mesocosms (approximately 5 ppm) and increased after Phaeocystis globosa blooms peaked, i.e. during the senescent phase of the blooms $(119,76$, and 116 ppm in Mesocosms 1, 2 and 3, respectively).

For all sampling occasions, the power relationship fitted the TEP size spectra well. In Mesocosms 1 and 2, the spectral slope, $\delta$, increased significantly $(\mathrm{p}<5 \%)$ from Day 2 to Day 18 (from -3.96 to -2.38 and from -4.38 to -2.11 for Mesocosms 1 and 2, respectively), i.e. the fraction of large TEP increased. Although $\delta$ remained relatively constant in Mesocosm 3 during the course of the bloom, large TEP were produced between Day 2 and Day 14 (i.e. larger TEP appeared between successive sampling occasions).

\section{Free, attached and total bacterial concentration}

Bacterial concentration obtained using flow cytometry was compared with predicted total bacterial concentration estimated as the sum of microscope counts of free bacteria and expected number of TEP-attached bacteria. We excluded data for which the slope, $\delta$, of the TEP size spectra was $>-3$ from the regressions, because when the fraction of large TEP increases (i.e. when $\delta$ increases) large TEP distribution is too sparse and counting statistics may become inaccurate and utilizing these data may, thus, introduce an error when estimating the number of attached bacteria. Free bacterial concentrations, determined using epifluorescence microscopy, represented $59 \pm 13 \%$ of the total bacter- 
ial population, and TEP-attached bacteria represented $\sim 40 \%$ (slope of bacterial concentration estimated by microscopy versus bacterial concentration estimated by flow cytometry; Fig. 2). Comparison between predicted and observed total bacterial concentrations showed that attachment to TEP explains up to $95 \%$ of the observed total bacterial concentration (Fig. 2).

In all mesocosms, bacterial concentrations (total observed, total expected or free) were positively correlated to TEP concentration (Fig. 3). Estimates of the fraction of bacteria available for protozoans, as a function of the maximum particle size on which a given group can graze upon, were obtained by combining TEP size spectra from the 3 mesocosms and the TEP size versus number of attached bacteria relationships. Depending on food size-selectivity, over the size range investigated (particles $<12 \mu \mathrm{m}$ ), 73 to $97 \%$ of the total bacterial population is available for protozoan grazing (Fig. 4).

\section{Protistan community composition and concentration}

Strombidium spp. and Euplotes spp. (mainly E. vannus) dominated the mesocosms at different stages of Phaeocystis globosa blooms (Fig. 5). A few Tintinnids and Mesodinium spp. were also observed, but their abundance remained very low $\left(<2 \mathrm{ml}^{-1}\right)$ and their occurrence was not correlated to variations in TEP volume concentration.

In Mesocosms 1 and 3, the concentration of Strombidium spp. was high (from 5 to $20 \mathrm{ml}^{-1}$ ) and dominated the protistan community until TEP volume concentration rose from less than 10 ppm up to 40 ppm (Days 10 to 12); thereafter Euplotes spp. emerged. For TEP volume concentration $>40 \mathrm{ppm}$, Strombidium spp. simply disappeared, while Euplotes spp. became the dominant species with concentrations ranging from 5 to $12 \mathrm{ml}^{-1}$.

In Mesocosm 2, the protistan community behaved somewhat differently, as Strombidium spp. did not disappear when TEP volume concentration reached $>40$ ppm, but only slightly decreased. Euplotes spp. also emerged when TEP volume concentration reached $\sim 40$ ppm and thereafter dominated the ciliate community with concentrations as high as $44 \mathrm{ml}^{-1}$.

Variations in the relative percentages of Strombidium spp. and Euplo-

Fig. 1. Differential transparent exopolymeric particle (TEP) size distribution and TEP volume concentrations during bloom growth under contrasting N:P molar ratios. Regression lines were fitted to the data using $\mathrm{d} N / \mathrm{d}\left[d_{\mathrm{p}}\right]=k d_{\mathrm{p}}{ }^{\delta}$, where $d_{\mathrm{p}}$ is the equivalent spherical diameter (ESD) and $d N$ is the number of TEP particles per unit volume and per size class (no. $\mathrm{ml}^{-1} \mu \mathrm{m}^{-1}$ ) in the size range $d_{\mathrm{p}}$ to $\left[d_{\mathrm{p}}+\mathrm{d}\left(d_{\mathrm{p}}\right)\right](\mu \mathrm{m}) . \delta=$ spectral slope 


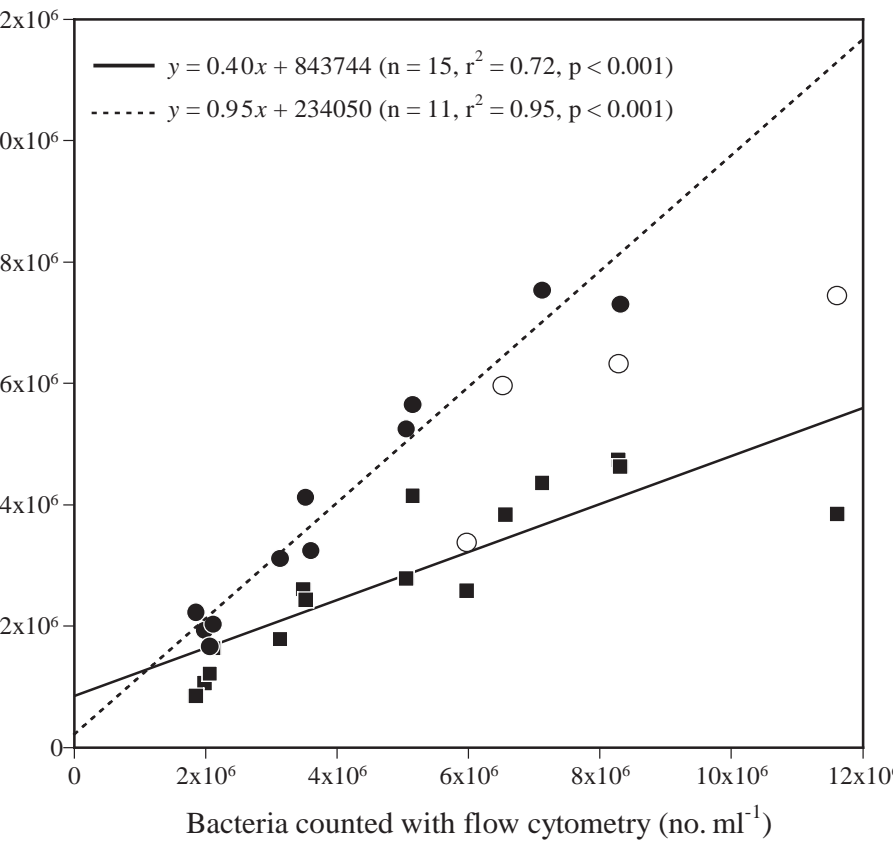

Fig. 2. Phaeocystis globosa. Comparison between total bacterial concentration $\left(\right.$ Bact $_{\text {Totali }}$ estimated by flow cytometry) and free bacterial concentration (Bact Freei $_{\text {estimated by epifluorescence }}$ microscopy, squares), and expected total bacterial concentration $\left(B a c t_{\text {Expected Totali }}\right.$ calculated as $B a c t_{\text {Free }}+$ Bact $_{\text {Expected Attached to TEP }}$ circles). Regression lines have been fitted to the data, but utilizing only data described by closed symbols

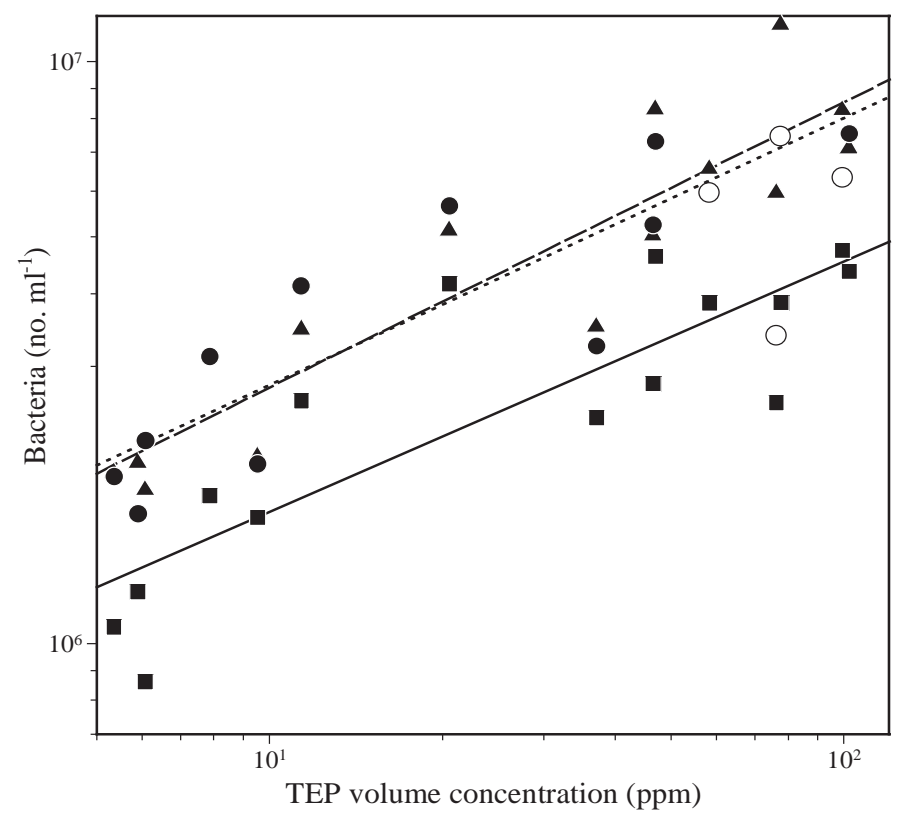

Fig. 3. Correlation between TEP volume concentration and the concentrations of: free bacteria (squares) $\left(r^{2}=0.73 ; n=15\right.$; $\mathrm{p}<0.001$ ), total bacteria measured by flow cytometry (triangles) $\left(\mathrm{r}^{2}=0.84 ; \mathrm{n}=15 ; \mathrm{p}<0.001\right)$, and expected total bacteria (circles) $\left(\mathrm{r}^{2}=0.75 ; \mathrm{n}=11 ; \mathrm{p}<0.001\right)$. Regression lines have been fitted to the data, but utilizing only data described by closed symbols tes spp. were closely correlated with changes in TEP volume concentration (Fig. 6). The inversion point (i.e. from Strombidium spp. to Euplotes spp. dominance) coincided with the early senescent phase of the blooms and the concomitant increase in TEP volume concentration (ultimately leading to the formation of large marine snow aggregates).

\section{Incubations with Strombidium sulcatum}

After $24 \mathrm{~h}$ of incubation, the percentage of Strombidium sulcatum attached to mucous aggregates increased from 13 to $20 \%$ to a maximum of $37 \pm 8 \%$ in seawater collected at Day 14 (Fig. 7). For the incubations conducted with seawater collected from Mesocosms 1 and 2 at Day 18 (during the senescent phase of the blooms), the percentage of $S$. sulcatum attached to mucous aggregates decreased drastically. In the mean time, the fraction of $S$. sulcatum still present in the medium (calculated as a function of initial concentration and for the 15 incubations) decreased to $51 \pm 22 \%$ after $24 \mathrm{~h}$ and to $37 \pm 18 \%$ after 48 h. $S$. sulcatum associated with large mucous aggregates were both present at their surface and embedded inside them (Fig. 8), suggesting that they were trapped rather than intentionally sitting on aggregates.

The percentage of Strombidium sulcatum attached to aggregates after $24 \mathrm{~h}$ of incubation correlated positively with TEP volume concentration,

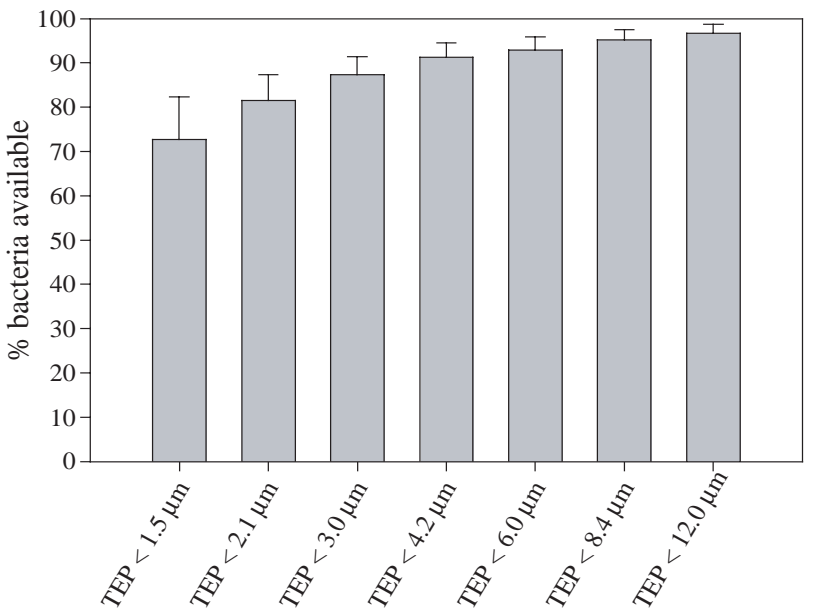

Fig. 4. Fraction of bacteria available for ciliate grazing according to the possible maximum aggregate size the ciliate Strombidium sulcatum can graze upon. The selected sizes (i.e. from 1.5 to $12.0 \mu \mathrm{m}$ ) correspond to the medium size of the TEP logarithmic size classes in the small size range 


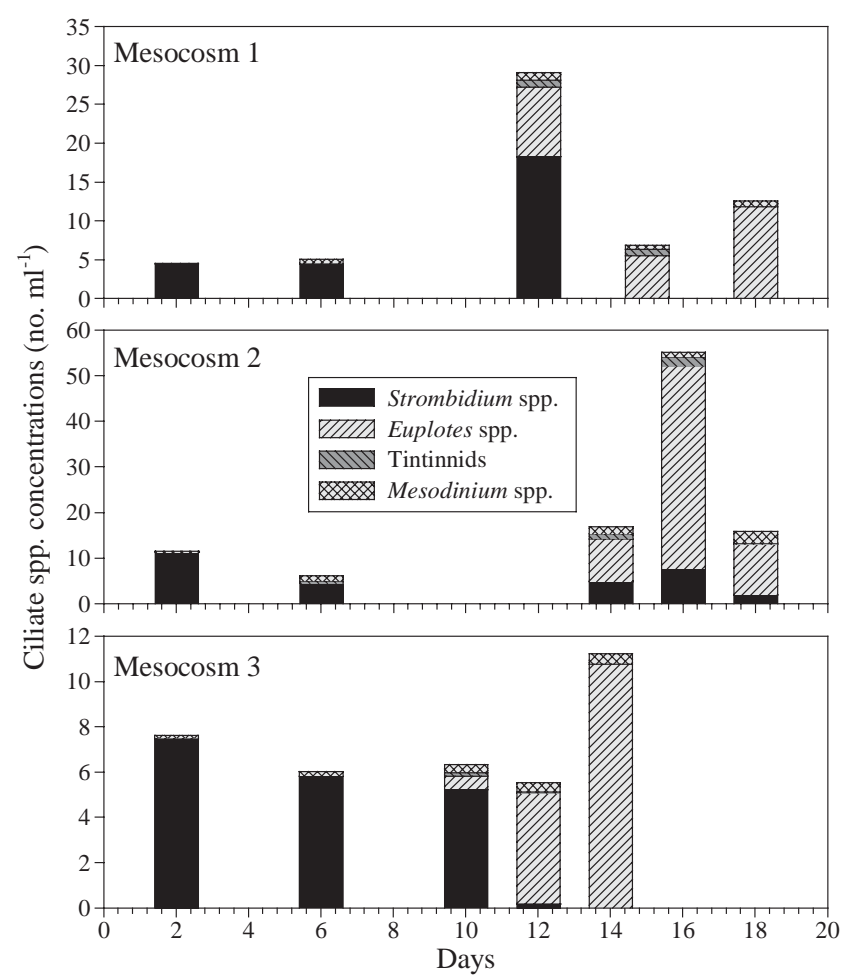

Fig. 5. Temporal variations of protozoan community composition in Mesocosms 1, 2 and 3 (note the different scales of the $y$-axes)



Fig. 7. Strombidium sulcatum. Temporal variations of the percentage attached to mucous aggregates after $24 \mathrm{~h}$ of incubation for Mesocosms $1(\bullet), 2(\square)$ and $3(\boldsymbol{\Delta})$

and the fraction of attached ciliates scaled with TEP volume raised to an exponent of 0.23 (Fig. 9), i.e. as the TEP pool accumulates, a larger fraction of the $S$. sulcatum population may become attached. We excluded the results obtained during the incubations with seawater collected from Mesocosms 1 and 2 on Day 18 from the regression analysis.
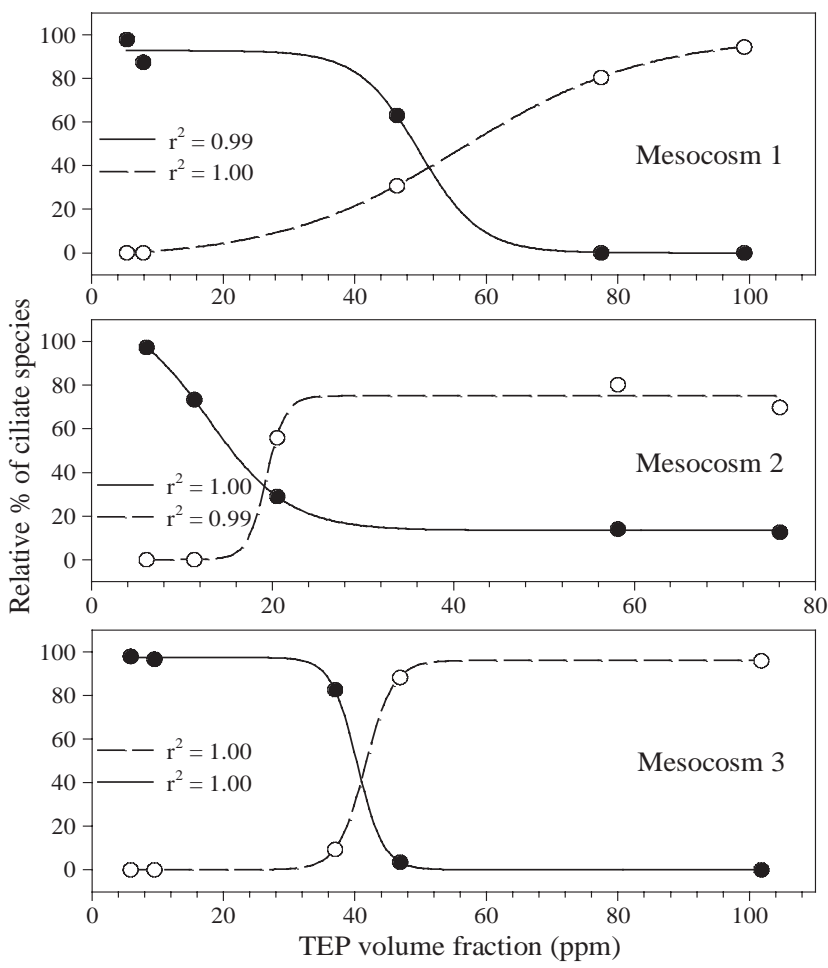

Fig. 6. Correlation between TEP volume concentration and relative percentage $(\mathrm{d} P)$ of Strombidium spp. (O) and $E u$ plotes spp. (O). Sigmoidal regression lines $\left(\mathrm{d} P / \mathrm{d}\left[\mathrm{TEP}_{\mathrm{vol}}\right]=\right.$ $\left.a\left\{1+\mathrm{e}^{-\left[\left(\mathrm{TEP}^{2} \mathrm{l}-\mathrm{TEPvol} 0\right) / b\right]}\right\}^{-1}\right)$ have been fitted to the data for each mesocosm

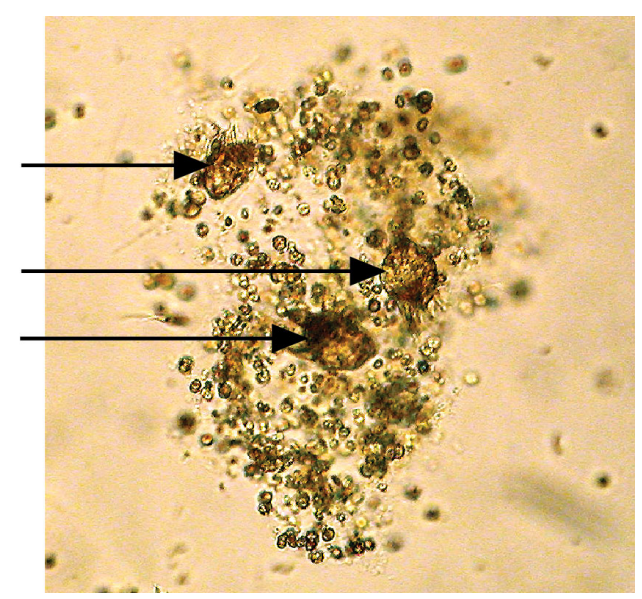

Fig. 8. Strombidium sulcatum. Examples (shown by arrows) attached to a macroaggregate

\section{DISCUSSION}

\section{Partitioning of the bacterial population}

The bacterial population in aquatic systems usually appears as both free and attached to particles, and estimations of the attached fraction vary from less 


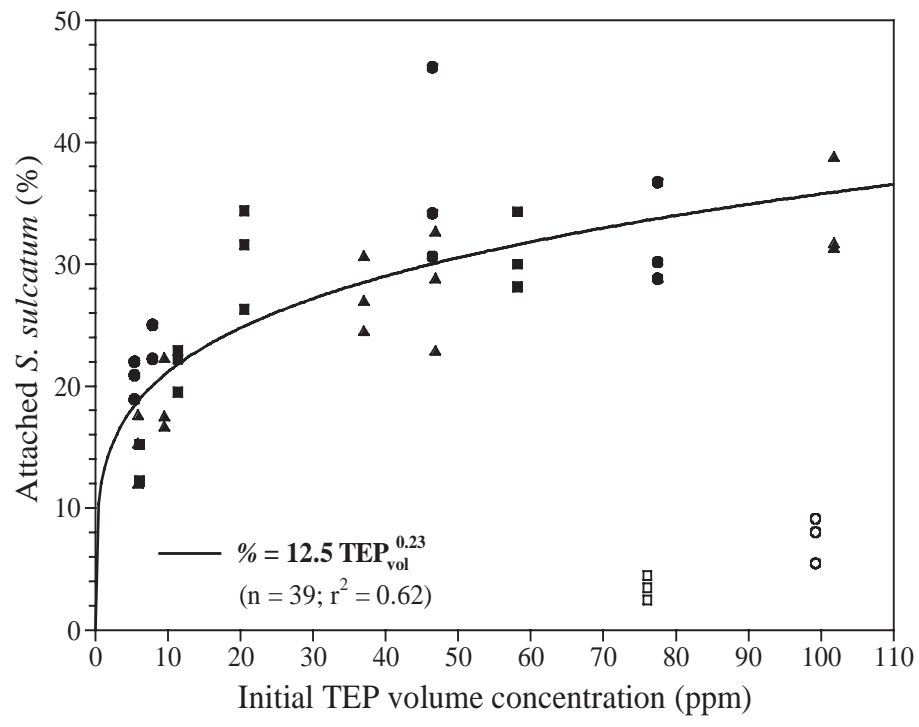

Fig. 9. Strombidium sulcatum. Percentage attached to mucous aggregates (\%) as a function of TEP volume concentration $\left(\right.$ TEP $_{\text {vol, }}$ ppm) for Mesocosms $1(\bullet, 0), 2(\boldsymbol{\square}, \square)$ and $3(\boldsymbol{\Lambda})$. Regression line $\left(\%=a \mathrm{TEP}_{\mathrm{vol}}\right)$ has been fitted to the data, but utilizing only data described by closed symbols

than $10 \%$ up to $90 \%$ of the total population (Bell \& Albright 1981, Robertson \& Newell 1982, Alldredge \& Youngbluth 1985, Albright et al. 1986, Alldredge et al. 1986, Herndl 1988). While the fraction of free bacteria is easily accessible microscopically, an estimate of the attached fraction is more difficult to obtain since it requires determination of the size distribution of the particles hosting bacteria and establishment of a relationship between the size of the particles and the number of attached bacteria. Therefore, for convenience and because large aggregates hosting bacteria are under-represented when studied in a limited number of fields at $1000 \times$ magnification, the number of bacteria attached to organic aggregates is generally not determined microscopically (especially when the concentration of large aggregates is high).

The number of TEP-attached bacteria was estimated from the TEP size spectra using the TEP size versus number of TEP-attached bacteria relationship obtained by compiling data recorded in the Kattegat (from Mari \& Kiørboe 1996). Although this relationship can only provide a crude estimate of the fraction of TEP-attached bacteria, this approach allowed us to confirm the hypothesis that attachment to TEP could explain the difference between free (determined microscopically) and total (determined by flow cytometry) bacterial populations. Therefore, the combined use of both methods can help to describe the structure of the bacterial population.
In the present study, the fraction of attached bacteria was $\sim 40 \%$ of the total bacterial population, which is high compared to previous estimates (i.e. average values from 0.5 to $25 \%$; Passow \& Alldredge 1994, Schuster \& Herndl 1995, Mari \& Kiørboe 1996). Our results support the hypothesis that the fraction of attached bacteria may increase along productivity gradients (Schuster \& Herndl 1995), as the Phaeocystis globosa mesocosms were highly eutrophic systems (i.e. TEP concentration up to 100 ppm and chlorophyll a concentrations $>20 \mu \mathrm{g} \mathrm{l}^{-1}$; C. P. D. Brussaard et al. unpubl. data).

\section{Succession of protists: influence of TEP concentration}

The present study suggests that TEP concentration is a significant controlling factor of the ciliate community structure. The ciliate Strombidium spp. dominated the protozoan community in all mesocosms when TEP concentration was relatively low (i.e. $<20$ ppm), while the ciliate Euplotes spp. became dominant in all mesocosms when TEP concentration reached a critical value (from 20 to 50 ppm). However, the observed difference between the community composition varied among mesocosms, suggesting that additional mechanisms besides TEP volume concentration may be important in structuring the ciliate community.

Strombidium spp. are typical filter feeders feeding on small-suspended food particles, such as nanoflagellates, bacteria and, to a lesser extent, picoplanktonic organisms (Allali et al. 1994, Dolan \& Šimek 1997. Christaki et al. 1998). They have an optimum food particle size of $\sim 3 \mu$ (Fenchel \& Jonsson 1988, Bernard \& Rassoulzadegan 1990, Mari \& Rassoulzadegan 2004) and are able to graze on free bacteria and aggregates $\leq 6 \mu \mathrm{m}$ (Bernard \& Rassoulzadegan 1990, Mari \& Rassoulzadegan 2004). Additionally, like most Oligotrichina, Strombidium spp. are truly free swimming protists and do not usually inhabit aggregates (Artolozaga et al. 2000). During their study of picoplankton-size prey analog grazing by $S$. sulcatum as a function of TEP concentration, Mari \& Rassoulzadegan (2004) showed that the food size spectrum was modified subsequent to enhanced TEP production and demonstrated that this process had a negative effect on the studied ciliate, which could ultimately lead to its disappearance. If prey concentration for Strombidium spp. decreases due to transfer of its food source to unreachable size classes, this ciliate population may decline and may gradually be superseded by other populations of ciliates feeding on larger particles or needing to sit on a physical support to feed.

The bacterial population structure (free vs. attached bacteria) was modified due to TEP-mediated aggrega- 
tion. However, the fraction of bacteria available for Strombidium spp. was high and relatively constant (ca. $90 \%$ ), and even increased over the course of the blooms, as bacterial and TEP concentrations were positively correlated. Therefore, reduction of bacteria availability does not seem to be directly responsible for the observed Strombidium spp. disappearance. The results obtained during the incubations conducted with $S$. sulcatum suggest that attachment to mucous aggregates may act as a loss factor for this ciliate (i.e. $S$. sulcatum were embedded inside mucous aggregates and, thereby, disabled). Assuming that TEP control upon Strombidium spp. abundance is due to their high sticking properties and subsequent direct scavenging by TEP aggregation, the diminution of the fraction of attached S. sulcatum observed for Mesocosms 1 and 2 at Day 18 could be due to a diminution in TEP stickiness or to a bad estimation of the fraction of attached $S$. sulcatum when aggregates started to age and to become denser (i.e. content hardly identifiable).

Euplotes spp. are poor swimmers, commonly found in benthic habitats, and the presence of large mucous aggregates in the water column may help them 'colonize' the epibenthic zone (and to some extent the pelagic zone). Such colonization may be achieved by swimming from one aggregate to another, using an active reversal response to the food gradient to locate food patches (Jonsson \& Johansson 1997). Unlike Strombidium spp., Euplotes spp. prefer to graze on attached bacteria while temporally attached to a solid surface (Albright et al. 1987, Patterson et al. 1993, Artolozaga et al. 1997). Therefore, large marine snow aggregates can be considered as environments in the pelagic zone that support populations with combined features allowing success in both pelagic and benthic systems. This mechanism of colonization may explain why benthic protists, known to be poorly adapted to pelagic lifestyle, are often observed inhabiting marine snow aggregates (Caron et al. 1982, Patterson \& Fenchel 1990). Hypotrichous ciliates, such as Euplotes spp. are specifically adapted to inhabit the surface and are known to be abundant in aggregate-rich environments (Caron et al. 1982, Davoll \& Silver 1986, Artolozaga et al. 2000, Woerner et al. 2000). An accumulation of TEP may, thus, favor the dominance of Euplotes spp. by promoting the formation of macroaggregates.

\section{Consequences for the microbial food web structure and function}

The consequences of high TEP production for the microbial food web structure and function could be divided into 2 processes. First, TEP production and the subsequent formation of mixed aggregates could act as a 'trophic elevator' by providing a direct lift for micrometer-size particles and dissolved organic carbon to higher trophic levels (Mari \& Rassoulzadegan 2004). Second, due to high sticking properties, the TEP-mediated aggregation of active components of the microbial food web (i.e. bacteria, heterotrophic nanoflagellates, ciliates) could cause a 'trophic jam' activating the trophic elevator by forcing a detour to higher trophic levels, thus inhibiting the microbial food web. Both mechanisms would minimize the significance of the microbial trophic web for the transfer of energy from the dissolved phase back to higher trophic levels.

Acknowledgements. This work was supported by the European Commission (Research Directorate General-Environment Programme-Marine Ecosystems) through the BIOHAB project 'Biological control of harmful algal blooms in European coastal waters: role of eutrophication' (contract EVK3CT99-00015). BIOHAB project is part of the EC EUROHAB cluster.

\section{LITERATURE CITED}

Albright LJ, McCrae SK, May BE (1986) Attached and freefloating bacterioplankton in Howe Sound, British Columbia, a coastal marine fjord-embayment. Appl Environ Microbiol 51:614-621

Albright LJ, Sherr EB, Sherr BF, Fallon RD (1987) Grazing of ciliated protozoa on free and particle-attached bacteria. Mar Ecol Prog Ser 38:125-129

Allali K, Dolan JR, Rassoulzadegan F (1994) Culture characteristics and orthophosphate excretion in a marine oligotrich ciliate, Strombidium sulcatum, fed heat-killed bacteria. Mar Ecol Prog Ser 105:159-165

Alldredge AL, Jackson GA (1995) Aggregation in marine systems. Deep-Sea Res Part I 42:1-8

Alldredge AL, Youngbluth MJ (1985) The significance of macroscopic aggregates (marine snow) as sites for heterotrophic bacterial production in the mesopelagic zone of the subtropical Atlantic. Deep-Sea Res 32:1445-1456

Alldredge AL, Cole JJ, Caron DA (1986) Production of heterotrophic bacteria inhabiting macroscopic organic aggregates (marine snow) from surface waters. Limnol Oceanogr 31: 68-78

Alldredge AL, Passow U, Logan BE (1993) The abundance and significance of a class of large, transparent organic particles in the ocean. Deep-Sea Res 40:1131-1140

Artolozaga I, Santamarìa E, Lòpez A, Ayo B, Iriberri J (1997) Succession of bacterivorous protists on laboratory-made marine snow. J Plankton Res 19:1429-1440

Artolozaga I, Ayo B, Latatu A, Azùa A, Unanue M, Iriberri J (2000) Spatial distribution of protists in the presence of macroaggregates in a marine system. FEMS Microbiol Ecol 33:191-196

Bell CR, Albright LJ (1981) Attached and free-floating bacteria in the Fraser River estuary, British Columbia, Canada. Mar Ecol Prog Ser 6:317-327

Bernard C, Rassoulzadegan F (1990) Bacteria or microflagellates as a major food source for marine ciliates: possible implications for the microzooplankton. Mar Ecol Prog Ser 64:147-155 
Caron DA, Davis PG, Madin LP, Sieburth JMcN (1982) Heterotrophic bacteria and bacterivorous protozoan in oceanic macroaggregates. Science 218:795-797

Christaki U, Dolan JR, Pelegri S, Rassoulzadegan F (1998) Consumption of picoplankton-size particles by marine ciliates: effects of physiological state of the ciliate and particle quality. Limnol Oceanogr 43:458-464

Dam HG, Drapeau DT (1995) Coagulation efficiency, organicmatter glues and the dynamics of particles during a phytoplankton bloom in a mesocosm study. Deep-Sea Res 42: 111-123

Davoll PJ, Silver MW (1986) Marine snow aggregates: life history sequence and microbial community of abandoned larvacean houses from Monterey Bay, California. Mar Ecol Prog Ser 33:111-120

Dolan JR, Šimek K (1997) Processing of ingested matter in Strombidium sulcatum, a marine ciliate (Oligotrichida). Limnol Oceanogr 42:393-397

Engel A (2002) Direct relationship between $\mathrm{CO}_{2}$ uptake and transparent exopolymer particles production in natural phytoplankton. J Plankton Res 24:49-54

Epstein SS, Shiaris M (1992) Size-selective grazing of coastal bacterioplankton by natural assemblages of pigmented flagellates, colorless flagellates, and ciliates. Microb Ecol 23:211-225

Fenchel T, Jonsson PR (1988) The functional biology of Strombidium sulcatum, a marine oligotrich ciliate (Ciliophora, Oligotrichina). Mar Ecol Prog Ser 48:1-15

Grossart HP, Simon M (1997) Formation of macroscopic organic aggregates (lake snow) in a large lake: the significance of transparent exopolymer particles, phytoplankton, and zooplankton. Limnol Oceanogr 42:1651-1659

Grossart HP, Berman T, Simon M, Pohlmann K (1998) Occurrence and microbial dynamics of macroscopic organic aggregates (lake snow) in Lake Kinneret, Israel, in fall. Aquat Microb Ecol 14:59-67

Hansen JLS, Kiørboe T (1997) Quantifying interspecific coagulation efficiency of phytoplankton. Mar Ecol Prog Ser 159:75-79

Herndl GJ (1988) Ecology of amorphous aggregations (marine snow) in the Northern Adriatic Sea. II. Microbial density and activity in marine snow and its implication to overall pelagic processes. Mar Ecol Prog Ser 48:265-275

Hewes CD, Holm-Hansen O (1983) A method for recovering nanoplankton from filters for identification with the microscope: the Filter-Transfer-Freeze (FTF) technique. Limnol Oceanogr 28:389-394

Hong Y, Smith WO, White AM (1997) Studies on transparent exopolymer particles (TEP) produced in the Ross Sea (Antarctica) and by Phaeocystis antarctica (Prymnesiophyceae). J Phycol 33:368-376

Jackson GA (1995) TEP and coagulation during a mesocosm experiment. Deep-Sea Res Part II 42:215-222

Jackson GA, Burd AB (1998) Aggregation in the marine environment. Environ Sea Technol 32:2805-2814

Jonsson PR, Johansson M (1997) Swimming behaviour, patch exploitation and dispersal capacity of a marine benthic ciliate in flume flow. J Exp Mar Biol Ecol 215:135-153

King LK, Parker BC (1988) A simple, rapid method for enumerating total viable and metabolically active bacteria in groundwater. Appl Environ Microbiol 54:1630-1631

Kiørboe T, Hansen JLS (1993) Phytoplankton aggregate formation: observations of patterns and mechanisms of cell sticking and the significance of exopolymeric material. J Plankton Res 15:993-1018

Kiørboe T, Tiselius P, Mitchell-Innes B, Hansen JLS, Wisser AW, Mari X (1998) Intensive aggregate formation with low vertical flux during an upwelling induced diatom bloom. Limnol Oceanogr 43:104-116

Mari X (1999) Carbon content and C:N ratio of transparent exopolymeric particles (TEP) produced by bubbling exudates of diatoms. Mar Ecol Prog Ser 183:59-71

Mari X, Burd A (1998) Seasonal size spectra of transparent exopolymeric particles (TEP) in a coastal sea and comparison with those predicted using coagulation theory. Mar Ecol Prog Ser 163:63-76

Mari X, Kiørboe T (1996) Abundance, size distribution and bacterial colonization of transparent exopolymeric particles (TEP) during spring in the Kattegat. J Plankton Res 18:969-986

Mari X, Rassoulzadegan F (2004) Role of TEP in the microbial food web structure. I. Grazing behavior of a bacterivorous pelagic ciliate. Mar Ecol Prog Ser 279:13-22

Mari X, Beauvais S, Lemée R, Pedrotti ML (2001) NonRedfield C:N ratio of transparent exopolymeric particles in the northwestern Mediterranean Sea. Limnol Oceanogr 46:1831-1836

Marie D, Partensky F, Vaulot D, Brussaard CPD (1999) Enumeration of phytoplankton, bacteria, and viruses in marine samples. In: Robinson JP, Darzynkiewicz Z, Dean PN, Orfao A, Rabinovitch PS, Stewart CC, Tanke HJ, Wheeless LL (eds) Current protocols in cytometry, Suppl 10. John Wiley \& Sons, New York, p 11.11.1-15

Mopper K, Zhou J, Ramana KS, Passow U, Dam HG, Drapeau DT (1995) The role of surface-active carbohydrates in the flocculation of a diatom bloom in a mesocosm. Deep-Sea Res 42:47-73

Passow U (2000) Formation of transparent exopolymer particles, TEP, from dissolved precursor material. Mar Ecol Prog Ser 192:1-11

Passow U (2002) Production of TEP by phytoplankton and bacteria. J Phycol 236:1-12

Passow U, Alldredge AL (1994) Distribution, size and bacterial colonization of transparent exopolymer particles (TEP) in the ocean. Mar Ecol Prog Ser 113:185-198

Passow U, Alldredge AL (1995) Aggregation of a diatom bloom in a mesocosm: the role of transparent exopolymer particles (TEP). Deep-Sea Res Part II 42:99-109

Passow U, Alldredge AL, Logan BE (1994) The role of particulate carbohydrate exudates in the flocculation of diatom blooms. Deep-Sea Res Part I 41:335-357

Passow U, Shipe RF, Murray A, Pak DK, Brzezinski MA, Alldredge AL (2001) Origin of transparent exopolymer particles (TEP) and their role in the sedimentation of particulate matter. Cont Shelf Res 21:327-346

Patterson DJ, Fenchel T (1990) Massisteria marina Larsen and Patterson 1990, a widespread and abundant bacterivorous protist associated with marine detritus. Mar Ecol Prog Ser 62:11-19

Patterson DJ, Nygaard K, Steinberg G, Turley C (1993) Heterotrophic flagellates and other protists associated with oceanic detritus throughout the water column in the Mid North Atlantic. J Mar Biol Assoc UK 73:67-95

Pernthaler J, Sattler B, Šimek K, Schwarzenbacher A, Psenner R (1996) Top-down effects on the size-biomass distribution of a freshwater bacterioplankton community. Aquat Microb Ecol 10:255-263

Porter GK, Feig YS (1980) The use of DAPI for identifying and counting aquatic microflora. Limnol Oceanogr 25:943-948

Riebesell U, Reigstad M, Wassmann P, Noji T, Passow U (1995) On the trophic fate of Phaeocystis pouchetii (Hariot): VI. Significance of Phaeocystis-derived mucus for vertical flux. Neth J Sea Res 33:193-203

Robertson JR, Newell SY (1982) Experimental studies of 
particle ingestion by the sand fiddler Uca pugilator (Bosc). J Exp Mar Biol Ecol 59:1-21

Schuster S, Herndl GJ (1995) Formation and significance of transparent exopolymeric particles in the northern Adriatic Sea. Mar Ecol Prog Ser 124:227-236

Sherr BF, Sherr EB, McDaniel J (1992) Effect of protistan grazing on the frequency of dividing cells in bacterioplankton assemblage. Appl Environ Microbiol 58: $2381-2385$

Simek K, Chrzanowski TH (1992) Direct and indirect evidence of size-selective grazing on pelagic bacteria by freshwater nanoflagellates. Appl Environ Microbiol 58: 3715-3720

Simek K, Vrba J, Hartman P (1994) Size selective feeding by Cyclidium sp. On bacterioplankton and various sizes of cultured bacteria. FEMS Microbiol Ecol 14:157-168

Editorial responsibility: Otto Kinne (Editor),

Oldendorf/Luhe, Germany
Šimek K, Bodkova J, Macek M, Nedoma J, Psenner R (1995) Ciliate grazing on picoplankton in a eutrophic reservoir during the summer phytoplankton maximum: a study at the species and community level. Limnol Oceanogr 40: $1077-1090$

Simek K, Hartman P, Nedoma J, Pernthaler J, Springman D, Vrba J, Psenner R (1997) Community structure, picoplankton grazing and zooplankton control of heterotrophic nanoflagellates in a eutrophic reservoir during the summer phytoplankton maximum. Aquat Microb Ecol 12:49-63

Stoderegger K, Herndl GJ (1999) Production of exopolymer particles by marine bacterioplankton under contrasting turbulence conditions. Mar Ecol Prog Ser 189:9-16

Woerner U, Zimmerman-Timm H, Kausch H (2000) Succession of protists on estuarine aggregates. Microb Ecol 40: $209-222$

Submitted: November 11, 2003; Accepted: May 27, 2004

Proofs received from author(s): September 10, 2004 